\title{
BOREAL: A tactical planning system for forest ecosystem management
}

\author{
by G.D. Puttock ${ }^{1}$, I. Timossi ${ }^{2}$ and L.S. Davis ${ }^{2}$
}

BOREAL is a tactical planning system designed to aid forest managers in developing site-specific management schedules consistent with planning objectives and environmental standards. The system projects outcomes of management alternatives in terms of future forest conditions and forest products and displays results in tabular, graphic, and map formats. The application of the system in a tactical management planning situation is demonstrated with an example of the interactions between timber production and moose (Alces alces L.) habitat for a 5,000 ha area in Algonquin Provincial Park, Ontario. The system is flexible and can be adapted to a variety of forest planning scenarios such as integrated timber production and habitat management, conservation of old growth forests, and protection of significant forest ecosystems.

Key words: Algonquin Park, geographic information system, linear programming, management planning, moose, timber supply, wildlife habitat

\section{Introduction}

It is now widely accepted that an integrated approach to forest ecosystem management is required to maintain the ecological integrity and productive capacity of the forest while providing multiple benefits to society (Heilman 1990, Kimmins 1992). Forest-level optimization models employing linear programming techniques, such as FORPLAN, can accommodate many non-timber outputs such as wildlife habitat, either within the objective function or as constraints according to the decision requirement (Paredes 1988; Thompson et al. 1994). The models are useful for strategic forest-level multi-resource planning (Sedjo 1987). However, the plans derived from these models are generally not site-specific and the step from strategic forest-level planning to tactical planning and implementation is often difficult (Covington et al. 1988, Davis and Martell 1993). In particular, long-term management plans may not be based on spatially optimal solutions (Kent et al. 1991; Nelson et al. 1991) or site-specific management prescriptions.

Forest managers are interested in the spatial and temporal forest-wide impacts of stand-level management activities on forest productivity and future forest conditions. Of particular complexity is the evaluation of future forest conditions, notably wildlife habitat, resulting from various harvest and other management schedules (Koten et al. 1991). Recently, a number of decision support systems have been developed to address the problems of timber production-wildlife habitat interactions, (e.g., Covington et al. 1988, Koten et al. 1991, Barrett and Davis 1994).

${ }^{1}$ Silv-Econ Ltd. 913 Southwind Ct., Newmarket, Ontario, Canada L3Y 6J1. ${ }^{2}$ Department of Environmental Science, Policy, and Management, University of California at Berkeley, 145 Mulford Hall, Berkeley, Califomia, U.S.A. 94720.
BORÉAL est un système de planification tactique destiné à aider les gestionnaires des forêts à élaborer pour des sites spécifiques des programmes de gestion cohérents avec les objectifs de planification adoptés et les normes de protection de l'environnement. Le système prévoit les conséquences des diverses options de gestion en termes des produits forestiers et des conditions forestière futures, et il peut afficher les résultats sous forme de tableaux, graphiques et cartes. Un exemple de l'interaction entre la production de bois et l'habitat des orignaux (Alces alces L.) dans un secteur de 5000 ha du parc provincial Algonquin (Ontario) illustre l'application du système dans une situation de planification tactique de la gestion. Le système est flexible et est adaptable à une variété de scénarii de planification forestière, tels que la production du bois d'oeuvre et la gestion de l'habitat, la préservation des forêts au peuplement mûr et la protection d'écosystèmes forestiers importants.

Mots-clés : Parc Algonquin, système d'information géographique, programmation linéaire, planification de la gestion, orignaux, ressources de bois, habitat de la faune.

BOREAL is a tactical planning system designed to aid forest managers in developing site-specific management schedules. It projects outcomes of management alternatives in terms of future forest conditions and forest products and displays results in tabular, graphic, and map formats. The results allow managers to evaluate alternative policies, objectives, and management strategies.

\section{System Description}

BOREAL is an interactive system organized around the use of commercially-available software for accessing, retrieving and evaluating database information, a linear programming (LP) simulation model for testing alternative policies and environmental constraints, and a geographic information system (GIS) for evaluating spatial interactions and mapping future forest conditions. The BOREAL system consists of:

- A relational database management system that can run database programs and process dBASE format files;

- Spreadsheet Assisted Resource Analysis (SARA) (Davis et al. 1991) programs and procedures for constructing the simulation model and reporting results;

- A spreadsheet program capable of saving files in Lotus 12-3 (.wk1) format (required for SARA);

- LINDO, a linear programming package;

- A presentation graphics package for charting the results of the LP simulations;

- A geographic information system for coverage management, spatial habitat analysis, and mapping;

- CLASSIFIER module, a series of classification programs to query and modify the database; and

- HABITAT module, a macro written in ARC/INFO aml to 
set spatial limits for aquatic habitat and to assign habitat quality indices.

All of the required software is commercially available. The CLASSIFIER programs and HABITAT macro are specific to the management planning problem under consideration and were developed by the authors. The system (Figure 1) makes use of existing geographic database information, such as forest inventory or forest cover databases. This assumes that digital geographic information containing forest coverages is available. If not, they would have to be created. BOREAL also relies on user-defined management prescriptions, objectives, planning horizon, number of periods for analysis, and environmental standards (e.g., wildlife habitat requirements).

As with other tactical planning models (Covington et al. 1988, Barrett and Davis 1994), BOREAL is designed for use in subforest areas such as watersheds, or blocks of up to 10,000 ha. The primary unit of analysis is the stand, defined as a contiguous area that is relatively homogeneous in terms of age class, site, and density. Stand attribute information is assembled into a database. From the initial data, additional fields can be created as might be required depending on the future forest conditions under consideration. Stand boundaries are considered fixed to facilitate projection of alternatives with the GIS, consistent with the approach followed by Barrett and Davis (1994).

The model assumes that stand-polygons with similar attributes can be classified into forest units or land types according to user-defined criteria. The initial assumption is that all stands within a given forest unit are subject to the same silvicultural prescription. However, the interactive nature of the model allows the user to reclassify any stand where alternate treatments are desired.

Classification of forest units can be done according to numerous criteria, and it is essential that the initial classification be compatible with the model objectives, such as projecting future wildlife habitat conditions (Barrett and Davis 1994). Thus a stand-polygon is assigned both a forest unit and a habitat type. Classifier programs are written to query the database for classifying or reclassifying polygons as required.

The forest manager chooses the planning horizon (e.g., 200 years) and the length of planning period (e.g., 20 years) so that economic and environmental variables are projected at discrete intervals. The manager also specifies a set of silvicultural prescriptions for each forest unit. The prescriptions represent alternative management strategies and may be defined according to age structure, density limits, species composition, or some combination of these. For example, stands of a given forest unit may be subject to a four-harvest uniform shelterwood system involving a preparatory cut at age 70 in which $50 \%$ of the basal area is harvested, a seeding cut at age 90 removing $45 \%$ of the basal area, first removal of $40 \%$ of the basal area at age 110 , and final harvest at age 130. After each entry, the residual stand is grown according to growth functions estimated from forest inventory data. Every forest unit has a prescription for no action.

Construction and estimation of the LP simulation model follows the procedures described by Davis et al. (1991) in the SARA programs and procedures. Most of the simulation model is formulated in a spreadsheet environment. The SARA technique accommodates multiple spreadsheets. For example, the manager can specify a separate spreadsheet for each forest unit. A spreadsheet consists of two parts: (i) a detached coefficient matrix, and (ii) a series of look-up tables containing yield tables and other user-defined information.

Each prescription for each forest unit represents a decision variable in the detached coefficient matrix in the LP simulation model. The outcomes of the analysis such as timber production, area harvested, pre-harvest inventory, and habitat components by period become the rows in the LP model. Numerous model formulations can be used to develop possible alternatives for a forest ecosystem management strategy. The solution as given by the LP model is the area of a forest unit assigned to a prescription and habitat type in each period.

Unlike other tactical models that require data from permanent sample plots or forest inventory plots to estimate stand inventories and structure (Barrett and Davis 1994, Koten et al. 1991), BOREAL makes use of existing empirical yield tables and growth functions derived from local inventories. This approach may limit the available information for habitat analysis, particularly if the inventory does not capture attributes such as crown ratio. However, the advantages of using empirical yield tables are the reduced data processing requirements and their simplicity of use. BOREAL allows the user to define one or more yield tables for each forest unit. For example, the manager may wish to specify one yield table for natural stand conditions and another yield table representing stands in a managed state for the same forest unit. The yield tables are entered in the spreadsheets as look-up tables.

Information regarding the habitat requirements for the wildlife species under consideration is used to construct habitat yield tables that are also entered as look-up tables in the spreadsheets. Since many species have several habitat requirements, BOREAL can accommodate more than one habitat yield table according to the initial forest unit and habitat type classifications. In the example of moose habitat that follows, there is a habitat yield table for each forest unit.

Habitat quality is determined according to aspatial (e.g., tree species, stand age) and spatial (e.g., adjacency between habitat types) criteria. BOREAL uses classifier programs to query the database regarding aspatial habitat characteristics and to assign an initial habitat quality to each stand-polygon in the GIS coverage. The model has a feedback loop that modifies the initial habitat quality for each stand to reflect the changes in habitat over time.

\section{An Example Application of the System}

An example of the interactions between timber production and moose (Alces alces L.) habitat for a 5,000 ha area in Algonquin Provincial Park, Ontario has been developed to demonstrate the application of BOREAL in a tactical management planning situation. Algonquin Provincial Park, situated in south central Ontario $\left(45^{\circ} 39^{\prime} \mathrm{N}, 78^{\circ} 39^{\prime} \mathrm{W}\right)$, is managed for multiple uses including camping, wilderness canoeing and hiking, wildlife habitat, and timber production. The park, $(7,685$ $\mathrm{km}^{2}$ ), has irregular topography over granitic bedrock, with mixed forests and numerous lakes. The forest cover in the park is typical of the Algonquin-Pontiac Section of the southern Great Lakes-St. Lawrence Forest Region (Rowe 1972). Sugar maple (Acer saccharum Marsh.), yellow birch (Betula allagheniensis Britt.) and eastern hemlock (Tsuga canadensis (L.) Carr.) primarily occupy the Precambrian uplands with moist soils on the west side of the park, while the eastern Ottawa lowlands, on the drier sandy soils on the east side contain red pine 


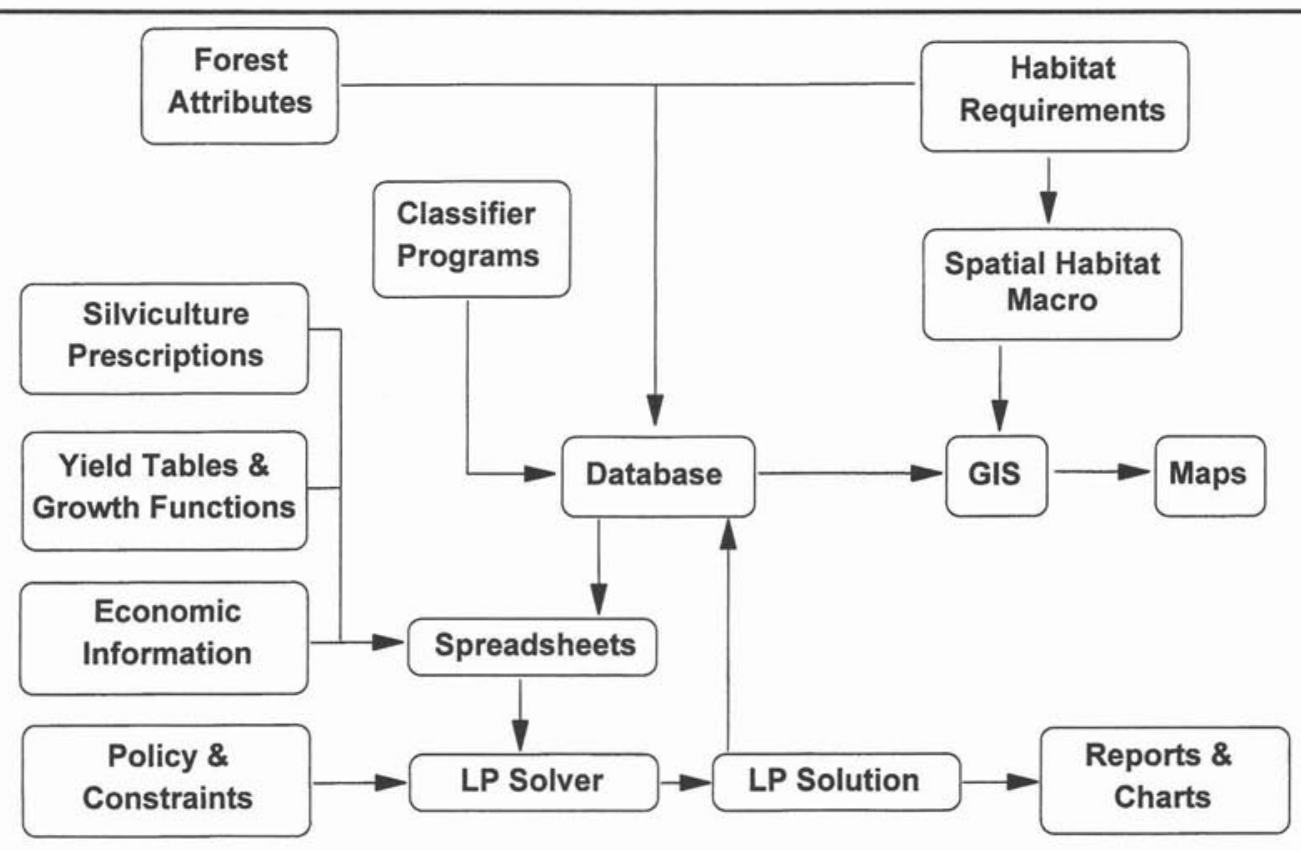

Fig. 1. BOREAL system flowchart.

(Pinus resinosa Ait.), eastern white pine (Pinus strobus L.), white birch (Betula papyrifera Marsh.), and aspen (Populus spp.), black spruce (Picea mariana (Mill) BSP) and jack pine (Pinus banksiana Lamb.) are found throughout the park (Wilton and Garner 1993). The diverse forest structure provides habitat to numerous wildlife species, including moose that have a population density of approximately 0.80 moose $\mathrm{km}^{-2}$ (Ontario Ministry of Natural Resources 1987-1995).

The study area was 5,000 ha situated in the west side of the park. Digital forest coverages (ARC/INFO format) were provided by the Ontario Ministry of Natural Resources. The primary database for the coverages is the 1987 Forest Resource Inventory (FRI). The FRI provides a general description of existing forest conditions and an information base for broad regional-level decision making and planning, including moose habitat interpretation (Jackson et al. 1991).

\section{Silviculture}

Timber production is an important management activity for Algonquin Park. In 1993/94, approximately $416,500 \mathrm{~m}^{3}$ of timber shipments valued at $\$ 240$ million were produced (Algonquin Forestry Authority 1994a). The regional target for the Algonquin Park Management Unit is to produce a continuous supply of up to $630,000 \mathrm{~m}^{3}$ of timber for the forest industry by the year 2020, while maintaining the present diversity of forest cover. The 1995-2000 target is to produce $415,000 \mathrm{~m}^{3}$ on an annual basis (Algonquin Forestry Authority 1994b).

A variety of silviculture systems are used in the park including (i) two-, three-, and four-cut uniform shelterwood harvesting for managing the spruce-fir, hemlock, and white/red pine forest units respectively, (ii) uneven-aged selection harvesting for the maple-yellow birch and mixed forest units, and (iii) even-aged clearcut harvesting for the aspen and white birch forest units. For the shelterwood and selection systems, har- vest criteria are specified according to the age at the time of each harvest and the basal area to be removed. In the even-aged clearcut system, all merchantable volume is harvested. Each of the forest units were present in the study area. Silviculture specifications and harvest criteria were provided by the Algonquin Forestry Authority.

The CLASSIFIER module within BOREAL was used to disaggregate the species composition fields within the FRI database into single species fields and assign a forest unit to each stand-polygon based on age class and species.

\section{The LP Model}

A 200-year planning horizon was established with 20year planning periods. Decision variables represented forest unit by prescription. The outcomes of the analysis included timber production (volume harvested), area harvested, preharvest inventory, and habitat types by period. Harvesting was assumed to take place at the beginning of each period. Harvest volumes were estimated from empirical yield tables (Plonski 1974) after adjusting for stocking and basal area to be removed. Following harvesting, the forest was aged and basal area was updated using basal area growth functions estimated from the yield tables. The end-of-period stocking and age class were used to assign coefficients to the habitat types within the detached coefficient matrix. For example, browse-producing area is created following a final harvest when a stand enters the regeneration phase $(<20$ year age class) or when the stocking is $<30 \%$ as might occur after an intermediate harvest. The end-of-period stocking and the growth functions were used to adjust yields at the beginning of the next period. The preharvest yields were entered as the coefficients to estimate preharvest inventory for each period.

The study area contains 2,031 ha of production forest. Of this, 1319 ha (64\%) are in the 101-120 and $121+$ age classes 
Table 1. Initial distribution of production forest in the study area by age class and forest unit (ha)

\begin{tabular}{|c|c|c|c|c|c|c|c|c|}
\hline \multirow[b]{2}{*}{ Forest unit } & \multicolumn{8}{|c|}{ Age class } \\
\hline & $1-20$ & $21-40$ & $41-60$ & $61-80$ & $81-100$ & $101-120$ & $121+$ & Total \\
\hline Mixed & 155 & 0 & 0 & 10 & 46 & 116 & 152 & 479 \\
\hline Tolerant hwd. & 0 & 0 & 0 & 0 & 0 & 86 & 832 & 918 \\
\hline Poplar & 0 & 0 & 0 & 0 & 10 & 0 & 0 & 10 \\
\hline Pine & 0 & 0 & 0 & 0 & 10 & 0 & 0 & 10 \\
\hline Hemlock & 0 & 0 & 0 & 0 & 0 & 0 & 17 & 17 \\
\hline Other conifers & 69 & 6 & 80 & 254 & 72 & 81 & 35 & 597 \\
\hline Total & 224 & 6 & 80 & 264 & 138 & 283 & 1,036 & 2,031 \\
\hline
\end{tabular}

while there are only 86 ha in the $21-40$ and $41-60$ age classes (Table 1). The imbalance in the age distribution of the forest presents an interesting challenge for forest managers. Timber production could be high in the first four 20 -year planning periods from 1996-2075 but could decline significantly during the intermediate periods from 2076-2115 as the initial 21-40 and 41-60 age classes reach maturity. Moose habitats, particularly the area of browse-producing habitat and late winter habitat, are also affected by the harvesting schedule. Forest managers might wish to consider policies that would reduce initial harvests and permit timber inventories to accumulate for the intermediate periods. Four management policies were considered in this example application of the BOREAL system: (A) maximize timber production, (B) maximize revenue, $(\mathrm{C})$ maximize timber production in period five, 2076-2095, and (D) maximize browse-producing habitat in period five. Sustained yield was imposed by subjecting policies to limitations on period-to-period variation on volume harvested. The general form of the constraint is:

$$
\mathrm{H}_{\mathrm{t}+1} \geq(1-\mathrm{a}) \mathrm{H}_{\mathrm{t}} \text { and } \mathrm{H}_{\mathrm{t}+1} \leq(1+\mathrm{b}) \mathrm{H}_{\mathrm{t}}
$$

where $\mathrm{H}$ represents volume harvested, $\mathrm{t}$ is period $\mathrm{t}(\mathrm{t}=1 \ldots 10)$, and $\mathrm{a}$ and $\mathrm{b}$ are the permitted proportional decrease and increase respectively in volume harvested.

Finally, constraints which limit the area of each forest unit and age class are specified as:

$$
\mathrm{AREAij}=\mathrm{X}
$$

where $i$ and $j$ represent the forest unit and age class respectively and $\mathrm{X}$ denotes area available for harvest.

For the various policies, the solutions were used to create new fields in the forest cover database to reflect the area harvested by forest unit in each period and the end-of-period habitat characteristics. The updated database was then used to create new ArcView GIS coverages for mapping habitat types and habitat quality for four 20 -year periods from 19962075 . The SARA system of programs and procedures contains modules that produce tables of time series variables from the LP output files. Some or all of the output variables and time periods can be specified. The tables can be printed in this form or imported into a graphics package to produce graphs and charts of the data.

\section{Habitat Requirements for Moose}

Habitats and population densities of moose are affected by aspatial characteristics such as tree species and aquatic veg- etation, and the spatial distribution of critical habitat components (Telfer 1984). Complex relationships between moose and predators, including anthropogenic influences, are also important (Stephens and Peterson 1984, Wilton and Garner 1991).

During spring and early summer, moose use aquatic and riparian habitats (Van Ballenberghe and Peek 1971, Botkin et al. 1973, Kearney and Gilbert 1976, Brusnyk and Gilbert 1983), where they can escape from insects and forage on macrophytes rich in sodium and iron (Jordan et al. 1973, Fraser et al. 1984). In the summer months nutritional demand is greatest while moose build energy stores for winter and replace energy expended while raising calves (Belovsky and Jordan 1978). Early successional species such as Populus tremuloides, Betula papyrifera, and Salix spp. found in recently harvested or disturbed areas are the preferred forage during this period (Kearney and Gilbert 1976, Peek et al. 1976, Addison et al. 1980). From mid- to late winter, weather conditions force moose to use mature, dense, conifer-dominated stands near suitable and adequate amounts of forage (Peek et al. 1976, Thompson and Vukelich 1981, Welsh et al. 1980). All of the habitat requirements of moose can be found in our 5,000 ha area study area.

Habitat suitability index models for moose have been developed for the Lake Superior region (Allen et al. 1987, Allen et al. 1991) and the northern Great Lakes-St. Lawrence Forest Region of Ontario (Naylor et al. 1992). Recently, Puttock et al. (1996) developed an empirical habitat model for moose in Algonquin Park in the southern Great Lakes-St. Lawrence Forest Region of Ontario. Based on these models, three habitat types were identified as: (i) browse- producing habitat consisting of all forest units $<20$ years of age and forest stands with $\leq 30 \%$ stocking (relative to the density of a normal stand); (ii) conifer and mixed summer-fall habitats represented by conifer forest units $>20$ years with $<50 \%$ stocking, and mixed forest units, i.e., stands with $>30 \%$ and $<70 \%$ hardwoods by basal area; (iii) late winter habitat consisting of conifer forest units $>20$ years with $\geq 50 \%$ stocking. Potential aquatic feeding areas were identified as a fourth habitat type. Allen et al. (1987) have suggested that riverine, lacustrine, and palustrine wetlands (as described by Cowardin et al. 1979), dominated by open water, emergent vegetation, or floating-leaved hydrophytes, can potentially provide sites for the production of aquatic vegetation preferred by moose. Unfortunately, the FRI does not classify wetlands in a way that would identify suitable aquatic feeding areas. Therefore, potential aquatic feeding areas were user-defined as: (i) lakes less than $2 \mathrm{ha}$, (ii) a $20 \mathrm{~m}$ ( $10 \mathrm{~m}$ inside and outside) buffer around all lakes greater than $2 \mathrm{ha}$, and (iii) all streams (a unique forest unit). 


\begin{tabular}{|c|c|c|c|c|c|c|}
\hline \multirow[b]{2}{*}{ Outcome } & \multirow[b]{2}{*}{ Year / period } & \multicolumn{2}{|c|}{$\begin{array}{c}\text { Policy A } \\
\text { Maximize total volume }\end{array}$} & \multirow[b]{2}{*}{$\begin{array}{c}\text { Policy B } \\
\text { Maximize } \\
\text { total } \\
\text { revenue }\end{array}$} & \multirow[b]{2}{*}{$\begin{array}{c}\text { Policy C } \\
\text { Maximize } \\
\text { volume } \\
2076-2095\end{array}$} & \multirow{2}{*}{$\begin{array}{c}\text { Policy C } \\
\text { Maximize } \\
\text { browse- } \\
\text { producing } \\
\text { habitat } \\
\text { 2076-2095 }\end{array}$} \\
\hline & & $\begin{array}{l}\text { A1: Limits on } \\
\text { period-to- } \\
\text { period } \\
\text { variation }\end{array}$ & $\begin{array}{l}\text { A2: No limits on } \\
\text { period-to- } \\
\text { period } \\
\text { variation }\end{array}$ & & & \\
\hline Volume harvested $\left(\mathrm{m}^{3}\right)$ & $\begin{array}{l}1996-2015 \\
2016-2035 \\
2036-2055 \\
2056-2075 \\
2076-2095\end{array}$ & $\begin{array}{l}27,742 \\
30,046 \\
36,056 \\
36,362 \\
29,089\end{array}$ & $\begin{array}{r}39,898 \\
18,494 \\
41,455 \\
47,446 \\
648\end{array}$ & $\begin{array}{l}28,671 \\
29,399 \\
35,279 \\
36,508 \\
29,206\end{array}$ & $\begin{array}{l}18,293 \\
22,596 \\
29,375 \\
38,187 \\
49,643\end{array}$ & $\begin{array}{l}20,337 \\
22,675 \\
29,477 \\
36,177 \\
47,030\end{array}$ \\
\hline $\begin{array}{l}\text { Browse-producing } \\
\text { habitat (ha) }\end{array}$ & $\begin{array}{l}1996 \\
2016 \\
2036 \\
2056 \\
2076\end{array}$ & $\begin{array}{l}533 \\
419 \\
474 \\
256 \\
180\end{array}$ & $\begin{array}{r}984 \\
83 \\
384 \\
416 \\
6\end{array}$ & $\begin{array}{l}556 \\
408 \\
490 \\
251 \\
176\end{array}$ & $\begin{array}{l}479 \\
377 \\
296 \\
303 \\
399\end{array}$ & $\begin{array}{l}487 \\
498 \\
123 \\
347 \\
416\end{array}$ \\
\hline Pre-harvest inventory $\left(\mathrm{m}^{3}\right)$ & $\begin{array}{l}1996 \\
2016 \\
2036 \\
2056 \\
2076\end{array}$ & $\begin{array}{l}247,758 \\
187,328 \\
153,138 \\
143,872 \\
162,222\end{array}$ & $\begin{array}{l}247,758 \\
123,928 \\
146,922 \\
167,163 \\
154,554\end{array}$ & $\begin{array}{l}247,758 \\
186,765 \\
154,989 \\
142,748 \\
160,256\end{array}$ & $\begin{array}{l}247,758 \\
204,174 \\
172,517 \\
173,262 \\
192,803\end{array}$ & $\begin{array}{l}247,758 \\
200,960 \\
156,626 \\
178,139 \\
199,554\end{array}$ \\
\hline $\begin{array}{l}\text { Total volume }\left(\mathrm{m}^{3}\right) \\
\text { Total revenue }(\$)\end{array}$ & $\begin{array}{l}1996-2195 \\
1996-2195\end{array}$ & $\begin{array}{r}395,117 \\
15,068,342\end{array}$ & $\begin{array}{r}419173 \\
15,864,388\end{array}$ & $\begin{array}{r}395,031 \\
15,069,600\end{array}$ & $\begin{array}{r}363,809 \\
13,987,980\end{array}$ & $\begin{array}{r}362,514 \\
13,929,112\end{array}$ \\
\hline
\end{tabular}

Again, the CLASSIFIER module was used to query the database and assign an initial habitat type and quality to each standpolygon. Stand-polygons that did not meet any of the above habitat criteria, including brush and alder and wetlands, were assigned to the "non" habitat type and given an initial quality rating of 0 . All suitable habitat types were assigned an initial quality rating of either low (1) or high (2) quality depending on species present and other criteria. Habitat quality was updated for the planning periods 2016-2035 and 2036-2055.

\section{Results and Discussion}

A number of management policies, involving different objectives and management strategies were evaluated. A separate control file is required for each policy alternative. This is accomplished by editing the objective function and/or constraints within the policy and constraints files. For this example application, the volume constraint limiting period-toperiod variation in timber production (Equation 1) was held constant for all management policies except for the policy maximizing timber production.

Selected results for the first five 20-year planning periods, 1996-2095, illustrate the capabilities of BOREAL and provide an interesting comparison of the outcomes under different management policies (Table 2). Results include total and periodic volume harvested, total revenue, area of browse-producing habitat by period, and pre-harvest inventory by period. The results for volume maximization without the volume constraint (Policy A2) illustrate the potential harvest flow problems that might occur when area and volume are not evenly distributed across age classes. The constraint is effective in balancing harvest volumes, pre-harvest inventory, and the area of browseproducing habitat across periods for any management policy.

There is little difference in the results of policies that maximize volume harvested (Policy A1) and revenue (Policy B) subject to the volume constraint. Revenue is determined by vol- ume harvested and log prices for the various forest units. $\log$ prices varied from $\$ 32-58 / \mathrm{m}^{3}$. However, in the study area $68 \%$ of the timber is in the tolerant hardwood and mixed forest units (Table 1) with log price of $\$ 55 / \mathrm{m}^{3}$. Therefore price differences do not contribute significantly to differences in revenue.

An important objective of forest planning is to consider the effects of policy alternatives of timber production on non-timber values such as wildlife habitat. Policies that maximize volume harvested (Policy C) and area of browse-producing habitat (Policy D) in period five, 2076-2095, have the desired effects. Pre-harvest inventory accumulates and is greater at the beginning of the fifth period under these policies than with policies which maximize either total volume or total revenue. This contributes to harvest levels and area of browse-producing habitat in the period 2076-2095 which are substantially higher than achieved in the same period under other policies. Total volume harvested and total revenue are also similar for policies $\mathrm{C}$ and $\mathrm{D}$.

The CLASSIFIER module was used to create new fields in the forest cover database to reflect the area harvested by forest unit in each period and the end-of-period habitat characteristics. The area harvested in any forest unit is an aggregation of stands within that forest unit. Stands to be harvested were selected interactively, a lengthy process. This is consistent with the approach followed in other planning models (Barrett and Davis 1994). Maps showing the distribution of moose habitat over time (e.g., 1996-2055) (Figure 2) can be produced by interfacing the enhanced database with the GIS. Interfacing the LP solution with the GIS also provides opportunities to evaluate the spatial effects, (e.g., adjacency between habitat components) under different management policies. Spatial criteria are evaluated on the GIS using one or more macros written specifically for the wildlife species under consideration.

The amount of browse-producing, summer-fall, and late winter habitat, and the area classed as non-habitat varies over time 

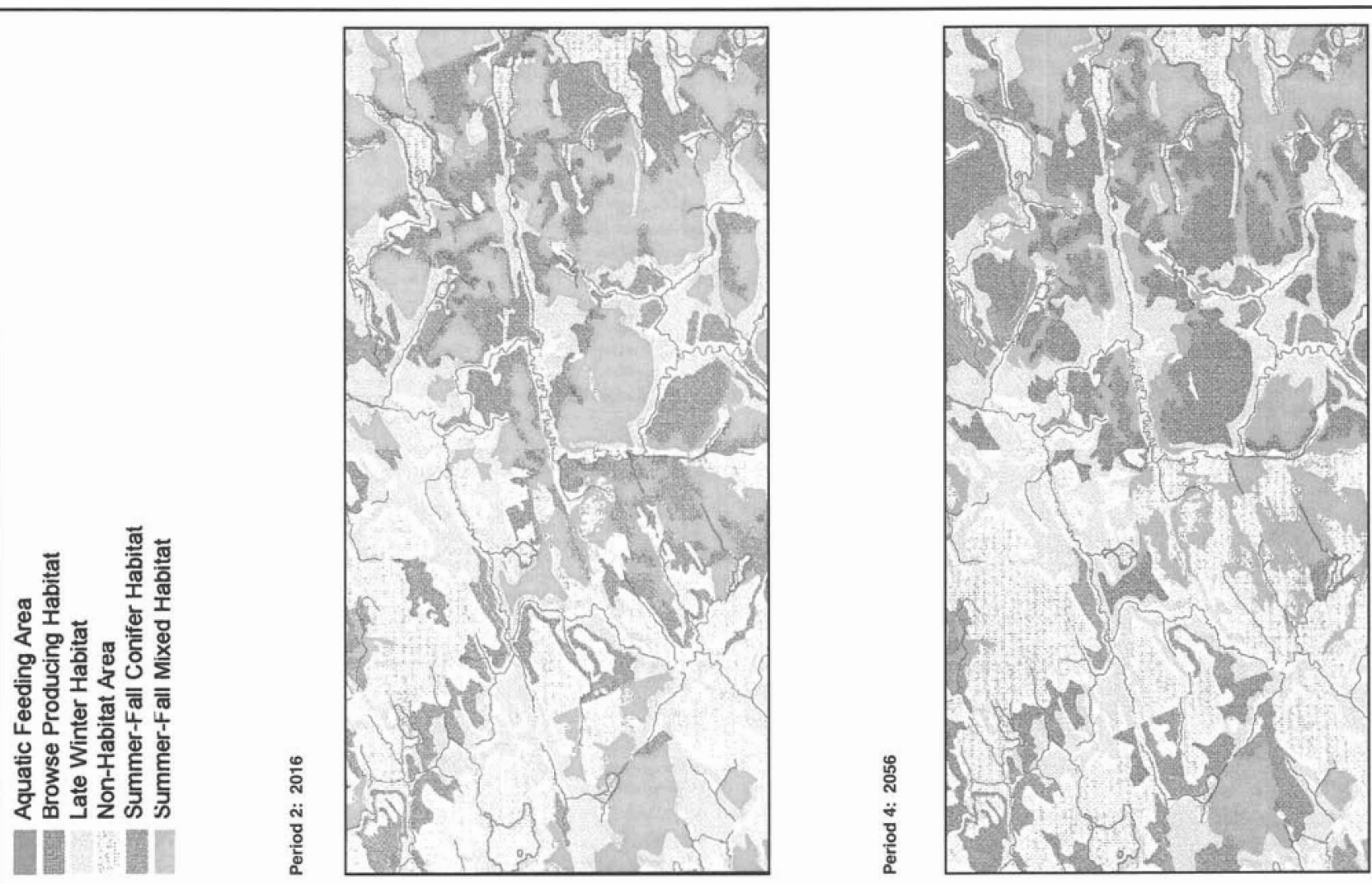

|0.
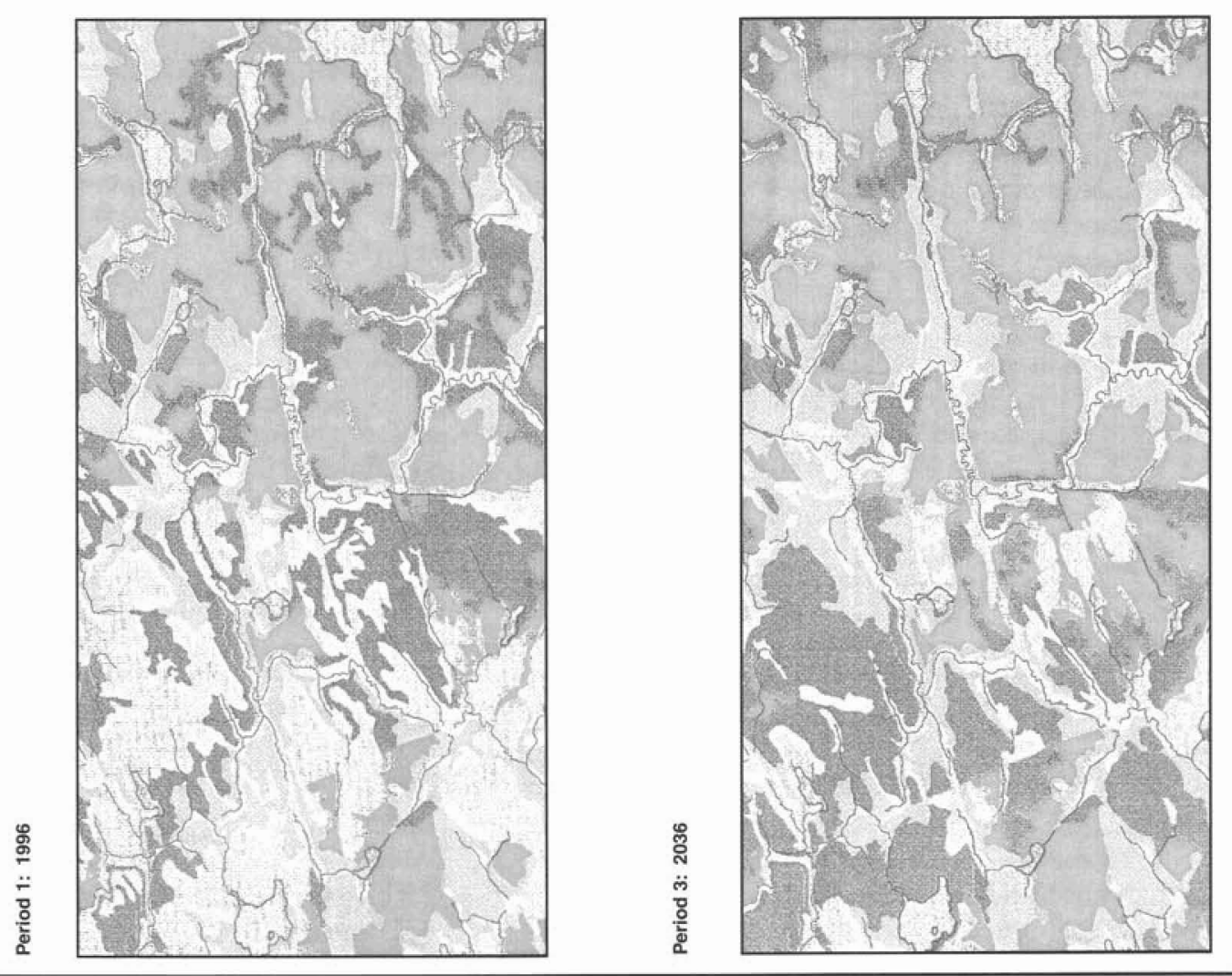
Table 3. Beginning-of-period moose habitat quality.

\begin{tabular}{|c|c|c|c|c|c|c|c|c|c|}
\hline \multirow[b]{2}{*}{ Habitat quality } & \multicolumn{3}{|c|}{ 1996-2015 } & \multicolumn{3}{|c|}{ 2016-2035 } & \multicolumn{3}{|c|}{ 2036-2055 } \\
\hline & None & Low & High & None & Low & High & None & Low & High \\
\hline Area (ha) & 1,615 & 2,980 & 403 & 1,575 & 2,785 & 639 & 997 & 3,379 & 623 \\
\hline
\end{tabular}

as the forest is harvested and as younger stands mature from browse-producing to other habitat types (Figure 2). The spatial distribution of the habitat types is also observed to vary with time (Figure 2). Managers can evaluate the possible effects on moose habitat from a number of management policy scenarios by linking the LP solutions with the GIS.

The quality of moose habitat is also expected to vary depending on harvest levels and management policies. A CLASSIFIER module was used to query the database and assign an initial habitat quality to each stand-polygon and to revise habitat quality. Policy A1 increases the area of low and high quality habitat in the second and third periods (Table 3). This can be attributed to an increase in browse-producing and summer-fall habitats. The changes in habitat quality over time can also be presented in maps if the information is to be displayed in management plans or at public forums.

Most of the simulation model is designed and built in a spreadsheet environment. The SARA technique accommodates multiple spreadsheets. For the example application, a separate spreadsheet was prepared for each forest unit in the study area. Each spreadsheet contained yield tables and other userdefined information specific to the forest unit involved. It is a simple procedure to edit the yield tables to reflect changes in forest conditions (e.g., site class or species composition) or to update other information such as product prices.

\section{Conclusions}

BOREAL is a prototype tactical planning system designed to aid in developing site-specific integrated forest ecosystem management schedules. It projects outcomes of management alternatives in terms of future forest and habitat conditions and forest products and displays results in tabular, graphic, and map forms. The results allow managers to evaluate alternative policies, objectives, and management strategies. The system is organized around the use of commercially-available database software, a linear programming simulation model, and a GIS. Two programs, CLASSIFIER and HABITAT, are used to query and update the database and to evaluate spatial habitat considerations respectively.

While the BOREAL system is fully operational for the planning problems experienced in the Algonquin Park example, it has not been tested for other forest planning scenarios. The system uses existing empirical yield tables and growth functions derived from local forest inventories. This approach may limit the available information for habitat analysis for many wildlife species, particularly if the yield tables do not provide sufficient details of forest structure.

Finally, the policies in the example application of the BOREAL system were deterministic, whereas in reality, fire, insects, diseases, among other sources, contribute to stochasticity (Barrett and Davis 1994). Including stochastic elements in the planning model requires specifying future outcomes and assigning probabilities to those outcomes.

Plans for future developments include a module for generating yield tables and growth functions from sample plot data and an automated process linking the LP output to the GIS. The analytical capabilities of BOREAL will also be expanded to accommodate other environmental considerations and desired future conditions.

\section{Acknowledgments}

We thank Carl Corbett, Algonquin Forestry Authority for guiding the development of the example application of the system. We are grateful to the anonymous referees for their helpful comments and suggestions.

\section{References}

Addison, R.B., J.C. Williamson, B.P. Saunders and D. Fraser. 1980. Radio tracking of moose in the boreal forest of northwestern Ontario. Can. Field Nat. 94(3): 269-276.

Allen, A., P. Jordan and J. Terell. 1987. Habitat suitability models for moose - Lake Superior region. U.S. Fish and Wildlife Service. Washington. $47 \mathrm{p}$.

Allen, A.W., J.W. Terrell, W.L. Mangus and E.L. Lindquist. 1991. Application and partial validation of a habitat model for moose in the Lake Superior region. Alces. 27(1991): 50-64.

Algonquin Forestry Authority. 1994a. Annual Report 1993-94. Huntsville, Ontario. 18 p.

Algonquin Forestry Authority. 1994b. Summary of 1995-2015 timber management plan for Algonquin Park management unit. Huntsville, Ontario. 51 p.

Barrett, T.M. and L.S. Davis. 1994. Predicting the spatial effects of forest management alternatives over multiple time periods. pp 817-820 In Proc. GIS'94 Symposium. Vancouver, BC.

Belovsky, G.E. and P.A. Jordan. 1978. The time-energy budget of a moose. Theor. Pop. Biol. 14: 76-104.

Botkin, D.B., P.A. Jordan, A.S. Dominsky, H.S. Lowendorf and G.E. Hutchinson. 1973. Sodium dynamics in a southern ecosystem. In Proc. Nat. Acad. Sci. U.S.A. 70: 2745-2748.

Brusnyk, L.M. and F.F. Gilbert. 1983. Use of shoreline reserves by moose. J. Wildl. Manage. 47: 673-785.

Covington, W.W., D.B. Wood, D.L. Young, D.P. Dykstra and L.D. Garrett. 1988. TEAMS: A decision support system for multiresource management. J. For. 86: 25-33.

Cowardin, L.M., V. Carter, F.C. Golet E.T. LaRoe. 1979. Classification of wetlands and deep water habitats of the United States. U.S. Fish and Wildlife Service. FWS/OBS-79/31. Washington. $131 \mathrm{p}$.

Davis, R.G. and D.L. Martell. 1993. A decision support system that links short-term silvicultural operating plans with long-term forestlevel strategic plans. Can. J. For. Res. 23(6): 1078-1095.

Davis, L.S., F. Schurr, J. Scott, R. Church, P. Daugherty, J. Beck and B. Beck. 1991. SARA. Spreadsheet Assisted Resource Analysis, User's Manual. Univ. of California at Berkeley. March 1991. 51 p. Fraser, D., E.R. Chavez and J.E. Paloheimo. 1984. Aquatic feeding by moose: selection of plant species and feeding areas in relation to plant chemical composition and characteristics of lakes. Can. J. Zool. 62: 80-87.

Heilman, P.E. 1990. Forest management challenged in the Pacific Northwest. J. For. 88: 16-23.

Jackson, G.L., G.D. Racey, J.G. McNicol and L.A. Godwin. 1991. Moose habitat interpretation in Ontario. Ont. Min. Nat. Resour., NWOFTDU Tech. Rep. 52.72 p.

Jordan, P.A., D.B. Botkin, A.S. Dominsky, H.S. Lowendorf and 
G.E.Belovsky. 1973. Sodium as a critical nutrient for the moose of Isle Royale. In Proc. North American Moose Conference-Workshop. 9: $13-42$.

Kearney, S.R. and F.F. Gilbert. 1976. Habitat use by white-tailed deer and moose on sympatric range. J. Wildl. Manage. 40: 645-657. Kent, B., B.B. Bare, R.C. Field, and G.A. Bradley. 1991. Natural resource land management planning using large-scale linear programs - The USDA Forest Service Experience with FORPLAN. Op. Res. 39(1): 13-27.

Kimmins, J.P. 1992. Balancing Act: Environmental Issues in Forestry. UBC Press, Vancouver. 244 p.

Koten, D.E., L.P. Herrington, R.E. Chambers and C.J. Davis. 1991. A knowledge-based approach to the evaluation of future forest conditions. pp. 386-390 In Proc. 1991 Symposium on Systems Analysis in Forest Resources. Gen. Tech. Rep. SE-74. USDA Forest Service, Charleston, SC.

Naylor, B.J., S. Chrisitlaw and P. Weilandt. 1992. Validation of a habitat suitability index model for moose in the northern portion of the Great Lakes-St. Lawrence Region of Ontario. COFTDU No.26. Ont. Min. Nat. Resour. North Bay, Ontario. 20 p.

Nelson, J., J.D. Brodie and J. Sessions. 1991. Integrating short-term, area-based logging plans with long-term harvest schedules. For. Sci. 37(1): 101-122.

Ontario Ministry of Natural Resources. 1987-1995. Moose census for Algonquin Provincial Park. 1987-1995. Unpublished data. Paredes, V.G.L. 1988. Design of a resource allocation mechanism for multiple use forest planning. In Proc. 1988 Symposium on Systems Analysis in Forest Resources. Gen. Tech. Rep. RM-161. USDA Forest Service, Fort Collins, Colorado. 278 p.

Peek, J.M., D.L. Urich and R.J. Mackie. 1976. Moose habitat selection and relationships to forest management in northeastern Minnesota. Wildl. Monogr. No.48. 65 p.

Plonski, W.L. 1974. Normal Yield Tables (Metric). Ont. Min. Nat. Res. Toronto, Ontario. 40 p.

Puttock, G.D., J.G. Rasaputra and P. Shakotko. 1996. An empirical habitat model foe moose, Alces alces, in Algonquin Park, Ontario. For. Ecol. and Manage. 81(1-3): 169-178.
Rowe, J.S. 1972. Forest regions of Canada. Canadian Forestry Service, Department of Fisheries and Environment. Publication No. 1300.172 p.

Sedjo, R.A. 1987. FORPLAN: An evaluation of a forest planning tool - summary. pp. 161-162 In FORPLAN: An evaluation of a forest planning tool. T.W. Hoekstra, A.A. Dyer and D.C. Master, eds. Gen. Tech. Rep. RM-140. USDA For. Serv., Fort Collins, CO.

Stephens, P. and R.O. Peterson. 1984. Wolf-avoidance strategies of moose. Holarctic Ecol. 7: 239-244.

Telfer, E.S. 1984. Circumpolar distribution and habitat requirements of moose (Alces alces). pp. 145-182 In R. Olson, R. Hastings and F. Geddes, eds. Northern Ecology and Resource Management. University of Alberta Press, Edmonton.

Thompson, I.D. and M.F. Vukelich. 1981. Use of logged habitats in winter by moose cows and calves in Northeastern Ontario. Can. J. Zool. 59: 2103-2114.

Thompson, W.A., M. Halme, S. Brown, H. Schreier and I. Vertinsky. 1994. Timber harvest scheduling subject to wildlife and adjacency constraints. In Proc. International Symposium on Systems Analysis in Forest Resources. September 6-9, 1994. University of California at Berkeley. Pacific Grove, CA. 482 p.

Van Ballenberghe, V. and J.M. Peek. 1971. Radiotelemetry studies of moose in northeastern Minnesota. J. Wildl. Manage. 35: 63-71.

Welsh, D.A., K.P. Morrison, K. Oswald and E.R. Thomas. 1980. Winter utilization of habitat by moose in relation to forest harvesting. In Proc. North American Moose-Conference-Workshop. 16: 398-428.

Wilton, M.L. and D.L. Garner. 1991. Preliminary findings regarding elevation as a major factor in moose calving site selection in south central Ontario, Canada. Alces. 27: 111-117.

Wilton, M.L. and D.L. Garner. 1993. Preliminary observations regarding mean April temperature as a possible predictor of tick induced hair loss on moose in south central Ontario, Canada. Alces 29: 197-200. 